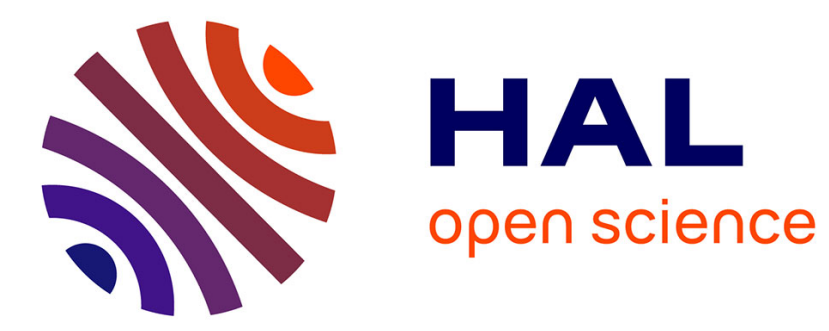

\title{
Soil nitrogen dynamics and crop residues. A review
}

Baoqing Chen, Enke Liu, Qizhuo Tian, Changrong Yan, Yanqing Zhang

\section{To cite this version:}

Baoqing Chen, Enke Liu, Qizhuo Tian, Changrong Yan, Yanqing Zhang. Soil nitrogen dynamics and crop residues. A review. Agronomy for Sustainable Development, 2014, 34 (2), pp.429-442. 10.1007/s13593-014-0207-8 . hal-01234828

\section{HAL Id: hal-01234828 \\ https://hal.science/hal-01234828}

Submitted on 27 Nov 2015

HAL is a multi-disciplinary open access archive for the deposit and dissemination of scientific research documents, whether they are published or not. The documents may come from teaching and research institutions in France or abroad, or from public or private research centers.
L'archive ouverte pluridisciplinaire HAL, est destinée au dépôt et à la diffusion de documents scientifiques de niveau recherche, publiés ou non, émanant des établissements d'enseignement et de recherche français ou étrangers, des laboratoires publics ou privés. 


\title{
Soil nitrogen dynamics and crop residues. A review
}

\author{
Baoqing Chen • EnKe Liu • Qizhuo Tian • \\ Changrong Yan $\cdot$ Yanqing Zhang
}

Accepted: 16 January 2014 / Published online: 28 February 2014

(C) INRA and Springer-Verlag France 2014

\begin{abstract}
Nitrogen $(\mathrm{N})$ is a major fertiliser for agriculture and food production. About 67.84 million tons of $\mathrm{N}$ are annually applied to agricultural fields, without which nearly half of the world's population would not be alive today. Returning plant residues to the soil is an alternative and sustainable way of $\mathrm{N}$ fertilisation. Although impacts of returning plant residues on plant available $\mathrm{N}$ in soil have been widely studied, there is still no systematic review of their mechanisms and models. In this review we highlight the following advances: (1) When plant residues are returned to the soil, $\mathrm{N}$ undergoes biotic immobilisation-remineralisation, abiotic immobilisation, soil organic $\mathrm{N}$ mineralisation and plant residue organic $\mathrm{N}$ mineralisation. (2) Plant residues modify inorganic $\mathrm{N}$ fate using three mechanism mineralisation, immobilisationmineralisation and immobilisation, depending on plant residue nature and soil properties. (3) The use of plant residue $\mathrm{C} / \mathrm{N}$ ratio is not always effective to predict the effect of plant residues. Instead, soil properties and the forms of carbon and nitrogen should be considered. (4) Mineralisation always promotes $\mathrm{N}$ uptake by crops and increases the risk of $\mathrm{N}$ loss. In addition, although net immobilisation is involved in immobilisation-mineralisation and immobilisation, it does not necessarily induce lower crop nitrogen uptake. Results also depend
\end{abstract}

B. Chen $\cdot$ E. Liu $(\varangle) \cdot$ C. Yan $\cdot$ Y. Zhang

Institute of Environment and Sustainable Development in

Agriculture, Chinese Academy of Agricultural Sciences,

Beijing 100081, People's Republic of China

e-mail: liuenke@caas.cn

B. Chen $\cdot$ E. Liu $\cdot$ C. Yan $\cdot$ Y. Zhang

Key Laboratory of Dryland Farming Agriculture, Ministry of

Agriculture of the People's Republic of China (MOA),

Beijing 100081, People's Republic of China

Q. Tian

State Key Laboratory of Crop Biology, Shandong Agriculture

University, Tai'an, China on the synchronism between the changing soil inorganic $\mathrm{N}$ and the crop $\mathrm{N}$ uptake. (5) $\mathrm{N}$ loss during mineralisation can be reduced by an immobiliser. Net $\mathrm{N}$ immobilisation during immobilisation-mineralisation and immobilisation can be reduced by changing the timing of ploughing and fertilising or by changing the plant residues placement.

Keywords Inorganic nitrogen · Plant residues · Crop nitrogen uptake

Contents

1. Introduction

2. The influences of plant residues on soil inorganic nitrogen pathways.

2.1 Biotic immobilisation-remineralisation...................2

2.2 Abiotic immobilisation...........................................

2.3 Soil organic nitrogen mineralisation.......................... 4

2.4 Organic nitrogen mineralisation of the plant residues.

3. Qualitative division and quantitative prediction of changing inorganic nitrogen process types due to plant residues

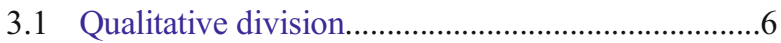

3.2 Quantitative prediction of different inorganic nitrogen pattern changes.

3.2.1 Predictions based on the integrated indexes......9

3.2.2 Predictions based on the first-order kinetic model .11

4. Synchronism between the soil inorganic nitrogen change patterns and crop nitrogen uptake.....................................12

4.1 Qualitative evaluation............................................13

4.2 Synchronism index..................................................15

5. Adjustment measures........................................................16

5.1 Mineralisation process..............................................16 
5.2 Immobilisation-mineralisation process and immobilisation process.

5.2.1 Ploughing and fertiliser application timing......17

5.2.2 The locations of the returned plant residues (mulching or incorporated into soil). .17

6. Conclusions. 18

\section{Introduction}

Nitrogen is one of most important elements for sustaining human life. Every year, about 67.84 million tons of nitrogen is applied to agricultural land all over the world (Liu et al. 2010). The total cost is up to $\$ 44.2$ billion. Nitrogen from ammonia, various synthetic nitrogen fertilizers are manufactured, without which nearly half of the world's population would not be alive today (Erisman et al. 2008). However, synthetic $\mathrm{N}$ fertilizer has become "too much of a good thing" because much of the $\mathrm{N}$ applied to cropland escapes the agricultural system and becomes a pollutant (Sutton et al. 2011). It is important to better understand the influence of different agricultural practices on soil mineral $\mathrm{N}$ dynamics to improve its use efficiency and reduce pollution.

Returning plant residue to the soil (Fig. 1) is an effective method for sustaining soil organic matter concentration, enhancing biological activities, improving physical properties and increasing nutrient availabilities (Smith et al. 1992). Organic matter is an essential soil component that is greatly affected by plant residue management. When plant residue or other organic sources are not returned to a soil, the soil biological fertility and resilience decreases as the physical, chemical and biological properties of the soil decline (Lal 1994; Kirchner et al. 1993; Wood and Edwards 1992; Perucci et al. 1997). This process results in low soil productivity. Moreover, large N, P, K and other nutrient concentrations can be available in plant residues for plant growth, which can improve long-term plant productivity. In addition, the return of plant residues to the soil can improve soil physical properties, which can reduce soil erosion risks (Freebairn and Boughton 1985; McGregor et al. 1990; Cassel et al. 1995) and improve the soil moisture retention (Bussière and Cellier 1994; Gill and Jalota 1996). Based on these benefits, more plant residues are being returned to farmlands throughout the world.

Soil inorganic nitrogen, which is derived from fertiliser nitrogen and soil organic nitrogen mineralisation, is the main form of plant available nitrogen. Historically, the relationships between plant residue quality and soil $\mathrm{N}$ dynamics have not been considered as important (Havlin et al. 1990). However, recent research has indicated that the properties of the returned plant residues influence the inorganic soil nitrogen concentrations. For example, higher quality plant residues, that are with

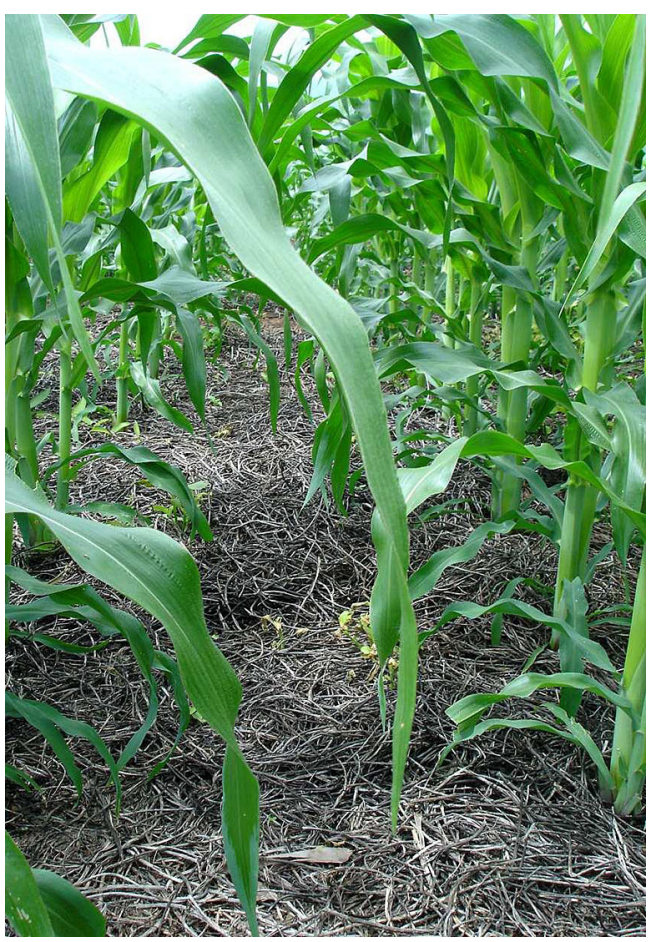

Fig. 1 Returning plant residues in the field. This widely applied agricultural practice can significantly improve soil quality and has uncertain influences on soil nitrogen dynamics

high $\mathrm{N}$ concentrations, low lignin and cellulose concentrations and low $\mathrm{C}: \mathrm{N}$ and lignin: $\mathrm{N}$ ratios often result in high $\mathrm{N}$ mineralisation rates. In contrast, low-quality residues have a lower $\mathrm{N}$ mineralisation rate that can negatively influence plant available nitrogen due to their effect on nitrogen immobilisation (Chaves et al. 2004; Gentile et al. 2009; Manzoni et al. 2008). Furthermore, changing inorganic nitrogen concentrations will affect the assimilation of nitrogen by plants and the potential nitrogen loss (Ichir and Ismaili 2002; Trinsoutrot et al. 2000; Sugihara et al. 2012). The changing inorganic nitrogen concentrations in plant residues that are returned to the soil and the crop nitrogen demand pattern have been widely studied recently. However, few systematic understanding regarding the mechanisms, process types and resulting quantitative models of soil inorganic nitrogen following the return of plant residues to soils has been established. In addition, the synchronism between different changing soil inorganic nitrogen process types and crop nitrogen uptake has not been determined. Here, the inorganic nitrogen changes that are caused by plant residues are defined as the differences between the soil inorganic nitrogen concentrations in soils with and without plant residues. Based on this definition, the objectives of this article are as follows: (1) to summarise the different inorganic nitrogen pathways during the return of plant residues; (2) to generalise different changing inorganic nitrogen process types and their classification standards; (3) to summarise the development of quantitative prediction models 
based on detailed indicators; (4) to assess the effects of inorganic nitrogen changes on crop nitrogen uptake and to establish a conceptual and quantitative model for the future; and (5) to discuss the adjustment measures to enhance the synchronism between inorganic nitrogen accumulation and plant nitrogen assimilation.

\section{The influences of plant residues on soil inorganic nitrogen pathways}

Soil inorganic nitrogen is derived from nitrogen fertilisers and soil organic nitrogen mineralisation. Inorganic nitrogen is subjected to a series of biochemical transformations in plant residues that are returned to the soil. Without considering the indirect influences of plant residues on soil nitrogen losses through leaching, runoff, denitrification, ammonification etc., four processes were found to influence the inorganic nitrogen pathways in soils with plant residues, including biotic immobilisation-remineralisation, abiotic immobilisation, soil organic nitrogen mineralisation and plant residue organic nitrogen mineralisation.

\subsection{Biotic immobilisation-remineralisation}

Plant residues deposited on soils are subject to biological degradation (Berg and McClaugherty 2008). During biological degradation, plant residue carbon is used in respiration by decomposers, which releases $\mathrm{CO}_{2}$ and provides energy. With this energy source, microbial communities absorb different nutrients from the soil to promote their propagation. Regarding inorganic soil nitrogen which comes from the mineralisation of soil and fertiliser, if the plant residue nitrogen does not satisfy the microbial growth requirements, it is absorbed by the microbial communities as a nitrogen source, i.e. immobilisation. Consequently, regardless of the $\mathrm{C}: \mathrm{N}$ ratio or residue placement, above or belowground, all the plant residue that is returned to the field will enhance the microbe biomass nitrogen concentration during the early decomposition stages (Bird et al. 2001; Sakala et al. 2000).

The microbially immobilised inorganic nitrogen supports microbial proliferation and can be reused in suitable environments. This process is referred to as remineralisation, which mainly results from microbial death. Microbial death potentially results from microbe-substrate interactions or from predatory microbial regulation (Zelenev et al. 2006). Regarding microbe-substrate interactions, when the plant residue $\mathrm{C}$ or soil nutrient concentrations are not sufficient for microbial proliferations, microbial death will occur. In this case, the microbial biomass nitrogen from the dead microorganisms will become available through enzymolysis. The C:N ratio of bacteria, fungi and their predators are 3.65-4.92, 8-10 and 5.16-6.83 and 8-11, respectively. As a result, the availability of nitrogen by predation results from the high consumption and low assimilation rate of predators (Ferris et al. 1998; Ferris et al. 1997; Griffin et al. 1972; Chen and Ferris. 1999). In this case, ammonium is released from live predators. Shindo and Nishio (2005) found that the remineralisation rates of wheat straw that was returned to the soil were $0.71,0.55$ and $0.29 \mathrm{mg} \mathrm{N} \mathrm{kg}^{-1}$ day $^{-1}$ after 7,28 and 54 days, respectively.

The increased inorganic nitrogen immobilisation in microbial biomass does not correspond with the observed decrease in the soil inorganic nitrogen concentration. The negative $\mathrm{N}$ balance in soil after incorporating plant residues may result from unknown organic nitrogen fractions, which is considered as microbial residual products, e.g. empty hyphae, dead microbial cell residues and cell exudates (Nishio and Oka 2003; Mueller et al. 1998; Shindo and Nishio. 2005). In addition, Kindler et al. (2009) reported that the $\mathrm{N}$ and $\mathrm{C}$ from microbial biomass are introduced into soil organic matter as microbial residues after cell death.

\subsection{Abiotic immobilisation}

Previously, researchers have indicated that nitrogen immobilisation is a biotic process (Mary et al. 1996; Frey et al. 2000). However, many researchers (Dail et al. 2001; Compton and Boone 2002) have recently shown that some ${ }^{15} \mathrm{~N}$-nitrate is removed from the extractable inorganic-N pool in sterilised soils. This nitrogen is subsequently detected in the soluble organic $\mathrm{N}$ fraction. This phenomenon is explained by the abiotic conversion of $\mathrm{NO}_{3}{ }^{-}$into dissolved organic $\mathrm{N}$ (Davidson et al. 2003). However, the effects of plant residues on this abiotic conversion have not been determined. Regardless of the nitrogen conversion process, inorganic nitrogen can be transformed to organic nitrogen directly without existing in microbe biomass. Moreover, some chemical constituents or plant residue decomposition products ,such as phenolic, lignin and tannic acid, can convert soil mineralisable organic nitrogen into recalcitrant nitrogen forms by chemical immobilisation (Shindo and Nishio 2005; Olk et al. 2006). Next, soil inorganic nitrogen may be reduced.

\subsection{Soil organic nitrogen mineralisation}

Plant residues can affect soil organic nitrogen mineralisation by different mechanisms. These mechanisms were hypothesised from different experimental results. For example, Shindo and Nishio (2005) observed the promotion of organic nitrogen mineralisation by plant residues, which potentially resulted from the increased native organic matter decomposition or from the accelerated microbial biomass $\mathrm{N}$ turnover. In contrast, Fontaine et al. (2003) and Bradley and Grenon (2006) observed negative effects, which resulted from the competition between the microorganisms specialised in 
fresh organic matter decomposition or the use of polymerised soil organic matter for energy and nutrient acquisition.

In addition, when plant residues are returned to the soil surface, the soil environment becomes cooler and wetter than the soil environment of bare soils (Power et al. 1989; Edwards et al. 2000; Ji and Unger. 2001). Consequently, the soil organic nitrogen mineralisation rate may differ (Fang et al.,2007; Tu et al. 2006).

\subsection{Organic nitrogen mineralisation of the plant residues}

Organic nitrogen mineralisation from plant residues can increase soil inorganic nitrogen concentrations. Shindo and Nishio (2005) found that nearly $10 \%$ of the organic nitrogen that was present in wheat straw was transformed into microbial biomass, and the soil inorganic $\mathrm{N}$ concentration which was derived from wheat straw varied between 1.93 and $2.37 \mathrm{mg} \mathrm{N} \mathrm{kg}^{-1}$.

Irrespective of $\mathrm{N}$ losses from soils with different soil inorganic nitrogen concentrations the direct effects of plant residues on soil inorganic nitrogen are shown in Fig. 2. When plant residues are returned to the soil, the mineralisation of plant residue nitrogen contributes to the soil inorganic nitrogen pool. The extent of this contribution depends on the quality of the plant residue. Although multiple studies have been conducted regarding the effects of plant residues on soil organic nitrogen mineralisation, no generalizations have been made. However, the abiotic immobilisation of nitrogen by plant residues can reduce the concentration of soil mineralisable organic nitrogen. Because the additional inorganic nitrogen in the plant residue is transformed into microbial nitrogen, the microbe biomass nitrogen, the microbial residual nitrogen and the subsequent nitrogen remineralisation rate are enhanced by adding straw residues to soil. However, the effects of plant residues on direct inorganic nitrogen transformations to soil organic nitrogen remain unknown.
Thus, plant residues influence soil inorganic nitrogen concentrations in the four following ways: (1) plant residue nitrogen mineralisation; (2) the uncertain effects of plant residues on soil organic nitrogen mineralisation; (3) increased microbial inorganic nitrogen immobilisation, microbial residual nitrogen and remineralisation rate (abbreviated as effect on microbial nitrogen) and (4) unknown effects on the abiotic transformation of inorganic nitrogen to soil organic nitrogen (abbreviated as abiotic transformation). Based on these mechanisms, we defined the effects of plant residues on soil inorganic nitrogen as shown in formula 1. In addition, the effect of plant residues on soil nitrogen mineralisation can be classified as immobilisation, remineralisation and microbial residual nitrogen. Apart from the residues nitrogen mineralisation, the soil nitrogen mineralisation effect, microbial nitrogen effect and abiotic transformation results can be determined from the priming effect (Kuzyakov et al. 2000). Thus, formula 1 can be expressed by formulas 2 or 3 .

$$
\mathrm{RE}=\mathrm{RNM}+\mathrm{SNM}+\mathrm{MNE}+\mathrm{AT}
$$

$$
\mathrm{RE}=\mathrm{RNM}+\mathrm{SNM}+\mathrm{IME}+\mathrm{REE}+\mathrm{RNE}+\mathrm{AT}
$$

$$
\mathrm{RE}=\mathrm{RNM}+\mathrm{PE}
$$

Where RE refers to effect of plant residues on soil inorganic nitrogen; RNM refers to residues nitrogen mineralisation; SNM refers to effect on soil nitrogen mineralisation; MNE refers to effect on microbial nitrogen; AT refers to abiotic transformation; IME, REE and RNE refer to the effect of straw on immobilisation, remineralisation and microbial residual nitrogen, respectively and PE refers to priming effect.

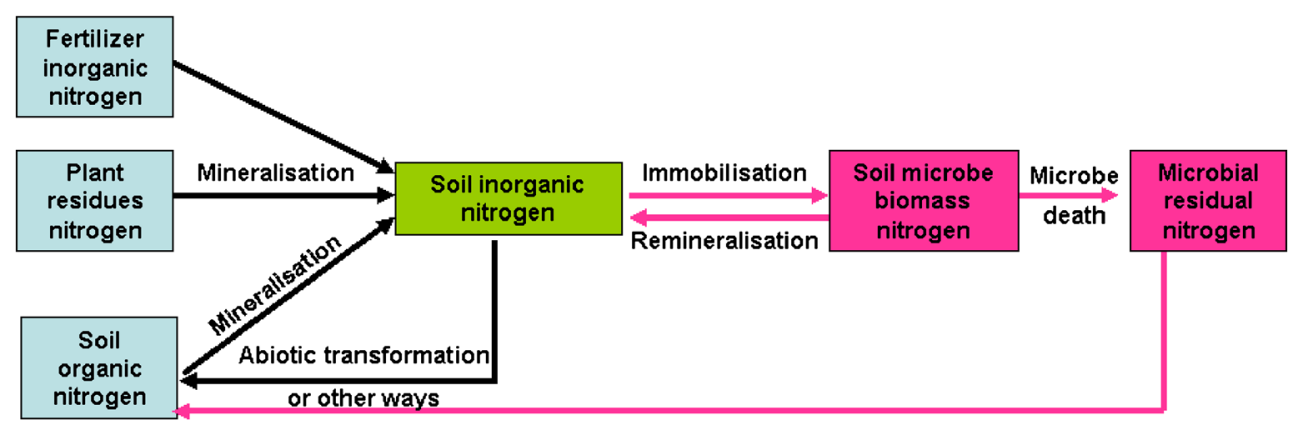

Fig. 2 The direct effect mechanisms of plant residues on soil inorganic nitrogen. Plant residues can provide inorganic to soils through residues nitrogen mineralisation. It is clear now that returning plant residues improve the immobilisation rate, remineralisation rate and microbe death and the corresponding soil microbe biomass nitrogen and microbial residual nitrogen. Influences of straw on soil organic nitrogen mineralisation and the abiotic transform of inorganic nitrogen have not been fully confirmed. These pathways describe how plant residues cause changes in soil inorganic nitrogen 
3 Qualitative division and quantitative prediction of changing inorganic nitrogen process types due to plant residues

\subsection{Qualitative division}

Many studies have examined inorganic nitrogen differences between soils with and without plant residues. These studies indicated that changes in inorganic nitrogen were always linked to the chemical characteristics of the plant residue, especially the C:N ratio. Typically, compared to soils without plant residues, only plant residues with $\mathrm{C}: \mathrm{N}$ ratios $<24$ increased the mineral $\mathrm{N}$ concentration (Trinsoutrot et al. 2000).

Based on a series of reports (Table 1), three process types were determined regarding the effects of returning plant residues to soils: mineralisation process, immobilisationmineralisation process and immobilisation process. We define the net immobilisation as decreasing inorganic nitrogen relative to the blank soils, and the net mineralisation as increasing inorganic nitrogen relative to the blank soils. These pathways were classified based on the occurrence and duration of net immobilisation over a limited period (Table 2). For mineralisation process, no net immobilisation occurs. In contrast, net immobilisation occurs in the early stages followed by net mineralisation for immobilisation-mineralisation process. Thus, immobilisation-mineralisation process is characterised by net mineralisation at the end of the experiment. For immobilisation process, no net mineralisation occurs throughout the experiment. A sketch of these patterns is provided in Fig. 3 and descriptions are provided in Table 2. The plant residues with C:N ratios of between 9.4 and 22.7 result in a mineralisation process. These plant residues include residues from vegetables, green manure and leguminous crops. Immobilisation-mineralisation process and immobilization process result from plant residues with $\mathrm{C}: \mathrm{N}$ ratios of $30.3-$ 136 and 46.5-99.4, respectively. The dividing line between immobilisation-mineralisation process and immobilization process is not absolute (Table 1). For example, wheat straw has a $\mathrm{C}: \mathrm{N}$ ratio of 79 , which results in a immobilisation process curve (Mohanty et al. 2010). However, wheat straw with a $\mathrm{C}: \mathrm{N}$ ratio of 136 results in a immobilisation-

Table 1 The different observed process types regarding the effects of the returned plant residues on soil inorganic nitrogen within the limited experimental period

\begin{tabular}{|c|c|c|c|c|}
\hline Process types & Plant residues & Plant residue $\mathrm{C}: \mathrm{N}$ ratio & Cultivation time & Reference \\
\hline \multirow[t]{10}{*}{ Mineralisation process } & Red cabbage fine roots & 21.6 & 4 months & Chaves et al. 2004 \\
\hline & White cabbage fine roots & 20.7 & 4 months & Chaves et al. 2004 \\
\hline & Savoy cabbage fine roots & 20.5 & 4 months & Chaves et al. 2004 \\
\hline & Leek roots & 11.2 & 4 months & Chaves et al. 2004 \\
\hline & Ryegrass leaves & 12.1 & 4 months & Chaves et al. 2004 \\
\hline & Ryegrass roots & 22.7 & 4 months & Chaves et al. 2004 \\
\hline & White mustard leaves & 9.4 & 4 months & Chaves et al. 2004 \\
\hline & White mustard stems & 19.2 & 4 months & Chaves et al. 2004 \\
\hline & Alfalfa shoots & - & 168 days & Trinsoutrot et al. 2000 \\
\hline & Oilseed rape leaves & - & 168 days & Trinsoutrot et al. 2000 \\
\hline \multirow[t]{7}{*}{ Immobilisation-mineralisation process } & Red cabbage large roots & 30.9 & 4 months & Chaves et al. 2004 \\
\hline & White cabbage large roots & 34.5 & 4 months & Chaves et al. 2004 \\
\hline & Savoy cabbage large roots & 30.3 & 4 months & Chaves et al. 2004 \\
\hline & Oilseed rape leaves & - & 168 days & Trinsoutrot et al. 2000 \\
\hline & Corn residues & 32.4 & 24 weeks & Hadas et al. 2004 \\
\hline & Rice hulls & 76.4 & 24 weeks & Hadas et al. 2004 \\
\hline & Wheat straw & 136 & 24 weeks & Hadas et al. 2004 \\
\hline \multirow[t]{7}{*}{ Immobilisation process } & Brussels sprouts large roots & 46.5 & 4 months & Chaves et al. 2004 \\
\hline & Maize straw & - & 168 days & Trinsoutrot et al. 2000 \\
\hline & Oilseed rape leaves & - & 168 days & Trinsoutrot et al. 2000 \\
\hline & Crop straw & 99.4 & 189 days & Chaves et al. 2005 \\
\hline & Cereal straw & 98.7 & 198 days & Chaves et al. 2006 \\
\hline & Rice straw & 86 & 14 weeks & Mohanty et al. 2010 \\
\hline & Wheat straw & 79 & 14 weeks & Mohanty et al. 2010 \\
\hline
\end{tabular}


Table 2 Feature descriptions of the different inorganic nitrogen change process types that resulted from returning plant residues to the soil

\begin{tabular}{llll}
\hline Process types & Net N immobilisation & Net N mineralisation & Final results \\
\hline Mineralisation process & Non-existent & Exist in all experimental period & Net N mineralisation \\
Immobilisation-mineralisation process & Exist at early stage & Exist at later stage & Net N mineralisation \\
Immobilisation process & Exist in all experimental periods & Non-existent & Net N immobilisation \\
\hline
\end{tabular}

mineralisation process curve (Hadas et al. 2004). Despite these different residue properties, the longer research period used by Hadas et al. (2004) potentially explains this difference. Thus, immobilisation process will not occur if the experimental period is long enough. However, limited crop growth periods cannot provide such a long period, especially in fields where annual plant residues are returned. Based on Table 2, the occurrence time of net mineralisation is a distinguishing standard for mineralisation process, immobilisation-mineralisation process.

If the nitrogen from plant residues is greater than the $\mathrm{N}$ demand of the microbial population during plant residue decomposition, plant residues nitrogen mineralization becomes dominant. Inversely, if the $\mathrm{N}$ concentrations in the plant residues are low, the inorganic nitrogen will be used by the microbial population and the effect of plant residues on microbial immobilisation becomes dominant.

Manzoni et al. (2008) hypothesised that net nitrogen mineralisation can be calculated as the difference between the total $\mathrm{N}$ that is available from litter decomposition and

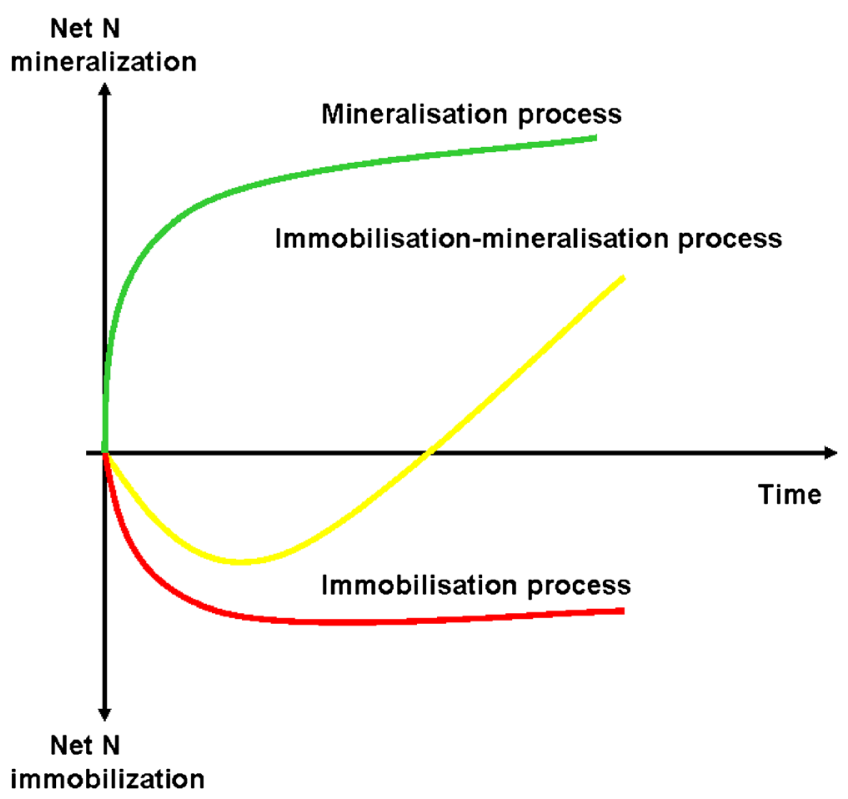

Fig. 3 Sketch of three different process types regarding the effects of returning plant residues on soil inorganic nitrogen over the limited experimental period. Net $\mathrm{N}$ mineralisation indicates that surplus inorganic nitrogen occurs in after plant residues are returned to the soil relative to the blank soil. Net $\mathrm{N}$ immobilisation indicates that the inorganic nitrogen concentration after returning plant residues to the soil is less than in the blank soil the $\mathrm{N}$ that is needed by the decomposers to assimilate $\mathrm{C}$ (formula 7).

$M=D\left(r_{L}-r_{C R}\right)$

$D=R_{B} /(1-e)$

$r_{C R}=e \cdot r_{B}$

$M=\frac{R_{B}}{(1-e)}\left(r_{L}-e \cdot r_{B}\right)$

Formula (5) was created from formulas (4) through (6), where $M$ is net nitrogen mineralisation, $D$ is the litter carbon decomposition rate, $r_{L}$ is the total $\mathrm{N}: \mathrm{C}$ ratio of the plant residue in the litterbag, $r_{C R}$ is the critical N:C ratio, $R_{B}$ is the plant residue $\mathrm{C}$ that is lost through respiration, $r_{B}$ is the biomass $\mathrm{N}: \mathrm{C}$ ratio of the decomposer and $e$ is the carbon use efficiency of the decomposer.

Thus, the maximum of the $\mathrm{N}$ release curve corresponds to the critical litter $\mathrm{N}$ concentration $\left(r_{C R}\right)$, which can be expressed analytically in terms of the $\mathrm{N}: \mathrm{C}$ ratio as a function of the characteristics of the decomposer $\left(r_{C R}=e \cdot r_{B}\right)$ (Manzoni and Porporato 2007). Therefore, when $r_{C R}<r_{L, 0}$, net mineralisation occurs at the beginning of decomposition and mineralisation process occurs in the soils with returned plant residues.

Regarding the value of carbon utilization efficiency of the decomposer, strong variations may occur that depend on environmental factors, substrate type (nutritional, elemental composition as well as energy content) and on biochemical degradation and assimilation pathways (Manzoni et al. 2012). However, $r_{B}$ does not vary systematically along gradients of organic matter and litter $\mathrm{N}: \mathrm{C}$ ratios and typically remains between 0.07 and 0.2 with an average value of 0.1 (Manzoni et al. 2008).

Thus, it is important to determine the value of carbon utilization efficiency for different ecosystems to determine which pattern exists in a soil with plant residue. In addition, 
these methods and the influence factors of carbon utilization efficiency are summarised by Manzoni et al. (2012).

The occurrence of mineralisation is a distinguishing standard for immobilisation-mineralisation process and immobilisation process. Theoretically, all plant residues will cause net mineralisation if the experimental period is long enough. However, limited crop growth periods may not provide a long enough period. C:N ratio is an important property of plant residues in the previous researches. A lot of pioneering work on residues decomposition rate index to the $\mathrm{C}: \mathrm{N}$ ration of residues was done by Martin Alexander in the 1980s (Stroo and Alexander 1986; Alexander 1985).

Several studies (Table 3) have determined empirical critical $\mathrm{C}: \mathrm{N}$ ratio values for net immobilisation and mineralisation that are helpful for distinguishing the immobilisation process from the mineralisation process and immobilisation process. The critical C:N ratio ranges from 24 to 44 , which suggests that the $\mathrm{C}: \mathrm{N}$ ratio of plant residues that cause immobilisation process should be greater than 44 .

\subsection{Quantitative prediction of different inorganic nitrogen pattern changes}

The effects of returning plant residues to soils on inorganic soil nitrogen are determined based on plant residue properties and soil factors (Heal et al. 1997; Khalil et al. 2005).

For many years, the $\mathrm{C}: \mathrm{N}$ ratio or the $\mathrm{C}: \mathrm{N}$ :polyphenol ratio was considered as the most important indicator for predicting $\mathrm{N}$ mineralisation during plant residue decomposition (Taylor et al. 1989; Thomas and Asakawa 1993). The C:N ratio of plant residues is a determinant for identifying the extent of inorganic nitrogen immobilisation (as shown in 2.1). In addition, polyphenols can form complexes with proteins, which render them inaccessible to microorganisms and slow down $\mathrm{N}$ mineralisation during the early stages of decomposition (Mafongoya et al. 1998; Mutabaruka et al. 2007).

Although the $\mathrm{C}: \mathrm{N}$ ratio is a useful index, the results that are predicted based on the $\mathrm{C}: \mathrm{N}$ ratio are not always correct. This is because different components of $\mathrm{C}$ and $\mathrm{N}$ have different stabilities. Hadas et al. (2004) found that the $\mathrm{N}$ recovery from tobacco residues was greater, which potentially resulted from the larger fraction $\mathrm{C}$ in the lignin-like pool although the gross $\mathrm{N}$ mineralisation of tobacco and rape residues were similar.
They also found that the $\mathrm{N}$ in rice hulls and in corn and wheat residues was dominantly recalcitrant. However, the rice hulls did not result in $\mathrm{N}$ deficiency because most of their $\mathrm{C}$ was also recalcitrant. Thus, these authors divided the total $\mathrm{C}$ and $\mathrm{N}$ into soluble, cellulose-like and lignin-like fractions.

Besides plant residue properties, several soil factors were gradually considered in new models (Khalil et al. 2005). However, these factors have not been thoroughly studied. Previously, many models, e.g. CENTURY model, DAISY model, were established that only used plant residue C:N ratios (Paustian et al. 1997; Magid et al. 1997). Here, we introduced quantitative prediction methods that were based on more detailed indexes of plant residue properties and soil factors.

\subsubsection{Predictions based on the integrated indexes}

Indexes that integrate plant residue properties and the soil factors can be used to predict soil inorganic nitrogen changes due to plant residues. These integrated indexes, including plant residue quality index, plant residue quality indexmodified and organic matter quality index, were gradually developed by researchers based on their correlations with soil inorganic nitrogen concentrations and can be used to predict different process types of changing inorganic nitrogen concentrations.

The plant residue quality index (PRQI) was developed by Tian et al. (1995) to evaluate the agronomic value of different plant residues. The C:N ratio and the lignin and polyphenol concentrations are important descriptors of plant residue quality. Therefore, these descriptors are defined by formula 8 :

$\mathrm{PRQI}=[1 /(a \mathrm{C}: \mathrm{N}+b$ lignin $+c$ polyphenols $)] \times 100$

Based on the coefficient between plant residues $\mathrm{C}: \mathrm{N}$, lignin, polyphenols and mean decomposition rate constants, the values of $a, b$ and $c$ were assigned as $0.423,0.439$ and 0.138 , respectively.

The PRQI was correlated with the plant residue decomposition rate, soil microclimate, soil fauna density and maize crop performance in the field. The soil moisture and termite density increased as the PRQI values decreased. In addition, the soil temperature, the ant density and the decomposition
Table 3 The empirical critical $\mathrm{C}: \mathrm{N}$ ratio values of the plant residues between net $\mathrm{N}$ mineralisation and net $\mathrm{N}$ immobilisation

\begin{tabular}{llll}
\hline Incubation environment & Incubation period & Critical C:N ratio & Reference \\
\hline Laboratory & $3-4$ months & 44 & De Neve and Hofman 1996 \\
Laboratory & 120 days & 36.6 & Chaves et al. 2004 \\
Laboratory & 11 weeks & 40 & Vigil and Kissel 1991 \\
Field & $>100$ days & & \\
Laboratory & 168 days & 24 & Trinsoutrot et al. 2000 \\
\hline
\end{tabular}


rate constants of the plant residues increased as the PRQI values increased.

Although the PRQI provided a method for assessing the agronomic value of plant residues, it has not been related to $\mathrm{N}$ dynamics. Therefore, Kumar and Goh (2003) proposed using the plant residue quality index-modified (PRQIM) model to relate the PRQI to changes in soil inorganic nitrogen. Three parameters are used in the PRQIM model, including the C:N, lignin: $\mathrm{N}$ and polyphenol: $\mathrm{N}$ ratios. The resulting equation is provided as formula 9:

PRQIM $=[1 /(0.526 \mathrm{C}: \mathrm{N}+0.349$ lignin $: \mathrm{N}+0.125$ polyphenol $: \mathrm{N})] \times 100$

The object of this study was to understand nitrogen release from plant residues. However, this study also measured the changing soil inorganic nitrogen concentrations of the soil with and without residues. According to a correlation test, the changing soil inorganic nitrogen concentrations were significantly correlated with PRQIM. This significant correlation occurred for the data that were obtained within this experiment and for independent data sets that were obtained from the literature.

Khalil et al. (2005) proposed the organic matter quality index (OMQI) to predict the decomposition rate, net $\mathrm{N}$ mineralisation and nitrification in different soil types under aerobic conditions. In their report, the net $\mathrm{N}$ mineralisation and nitrification were estimated by subtracting the accumulated mineral $\mathrm{N}\left(\mathrm{NH}_{4}{ }^{+}-\mathrm{N}+\mathrm{NO}_{3}{ }^{-}-\mathrm{N}\right)$ and $\mathrm{NO}_{3}{ }^{-}-\mathrm{N}$ at day 90 from that at day 0 . This index was used to determine the effects of the inherent soil and biochemical properties of the added organic materials on the $\mathrm{N}$ transformation processes. In addition, this index was used as a replacement for indicators that are difficult to measure in PRQI and PRQIM. The OMQI uses two parameters, including $\mathrm{pH}$ and the $\mathrm{C}: \mathrm{N}$ ratio (Eq. 10). The OMQI fit the decomposition rate constants well (61\%) with a corresponding prediction level of $67 \%$ when the soil property of $1 / \mathrm{CEC}$ (CEC, cation exchange capacity) was included (Eq. 11).

$\mathrm{OMQI}=[1 /(0.880 \mathrm{pH}+0.120 \mathrm{C}: \mathrm{N})] \times 100$

$\mathrm{OMQI}=[1 /(0.686 \mathrm{pH}+0.093 \mathrm{C}: \mathrm{N}+0.221 \times 1 / \mathrm{CEC})] \times 100$

The OMQI was significantly correlated with the decomposition rate constant, net mineralisation and nitrification in the soils that were treated with organic materials with or without the consideration of soil factors. The focus of the OMQI study was soil nitrogen mineralisation and nitrification in plant residues that were returned to the soil. Thus, to predict inorganic nitrogen changes due to plant residues, the soil inorganic nitrogen in the soils without added plant residues should be subtracted.

\subsubsection{Predictions based on the first-order kinetic model}

Although PRQIM and OMQI can predict net nitrogen mineralisation based on the quality of plant residues, they cannot predict changes in nitrogen mineralisation with time. However, prediction models based on the first-order kinetic model can solve this problem. The $\mathrm{N}$ mineralisation of plant residues as a function of time can often be described by the following first-order kinetics model: $\mathrm{AN}(t)=\mathrm{AN}[1-$ $\exp (-k t)]$, where $\mathrm{AN}$ is the amount of mineralisable $\mathrm{N}$, and $k$ is the rate constant. Similarly, the N mineralisation of plant residues can be measured as the difference between the inorganic nitrogen concentrations in the soils with and without plant residues. Therefore, the $\mathrm{N}$ mineralisation from the plant residues is equal to the inorganic nitrogen change that results from the plant residues.

De Neve and Hofman (1996) observed that the amount of mineralisable organic $\mathrm{N}$ was correlated with the chemical composition rather than the concentration of mineralisable total $\mathrm{N}$. In addition, these authors found that the amount of mineralisable organic $\mathrm{N}$ was best correlated with the $\mathrm{C}: \mathrm{N}$ ratio of lignin. Based on several $\mathrm{N}$ mineralisation measurements over a period of 3 to 4 months, these authors fixed the firstorder kinetics model to a new group of formulas as follows:

$\mathrm{N}(t)=\mathrm{N}_{\min }+\mathrm{N}_{\text {org }}(t) \cdot \frac{\mathrm{N}_{\text {org }}}{100}$

$\mathrm{N}_{\text {org }}(t)=\left(76.6-0.653\right.$ C-to- $\left.\mathrm{N}_{\text {lignin }}\right) \times\left(1-\mathrm{e}^{-\left(1.73-0.0144 \mathrm{~N}_{\text {org }}\right) \times t}\right)$

In formulas (12) and (13), $\mathrm{N}(t)$ represents the inorganic nitrogen change that results from the plant residues at time $t$, $\mathrm{N}_{\text {min }}$ represents the initial mineral $\mathrm{N}$ concentration in the plant residue and expressed as a percentage of total N. $\mathrm{N}_{\text {org }}(t)$ represents the percentage of organic $\mathrm{N}$ that is mineralised at time $t$. C-to- $\mathrm{N}_{\text {lignin }}$ represents the $\mathrm{C}: \mathrm{N}$ ratio of the lignin fraction. $\mathrm{N}_{\text {org }}$ represents the organic $\mathrm{N}$ concentration in the plant residues and expressed as a percentage of total $\mathrm{N}$. Compared to the disadvantage of PRQIM and OMQI in predicting nitrogen mineralisation changing with time, this model can be used to calculate the concentration of 
mineralised $\mathrm{N}$ at any specific time after incorporating the residues under the experimental conditions.

Similarly, Chaves et al. (2004) observed that the amount of mineralised $\mathrm{N}(\mathrm{AN})$ was best correlated with the $\mathrm{C}: \mathrm{N}$ ratio $(R=-0.86)$ and that the rate constant $k$ was best correlated with the lignin: $\mathrm{N}$ ratio $(R=-0.94)$. The resulting formula was expressed as follows: $\mathrm{AN}(t)=[-2.03 \mathrm{C}: \mathrm{N}+74.2] \times[1-$ $\left.\exp \left(-\left(2.93(\mathrm{~L}: \mathrm{N})^{-1.21}\right) t\right)\right]$. AN $(t)$ represents the amount of $\mathrm{N}$ mineralised at time $t$. C:N is the overall $\mathrm{C}: \mathrm{N}$ ratio of the crop residue. $\mathrm{L}: \mathrm{N}$ is the ratio of lignin to the total $\mathrm{N}$ concentration. In this formula, $\mathrm{C}: \mathrm{N}$ ration of crop residue is conveniently to be measured, but L:N ration is a more expensive measurement and will require a specialized test.

Formulas that are based on first-order kinetic models may be more effective for assessing inorganic nitrogen changes with time. However, existing research is too limited for obtaining a universal curve. Moreover, the influencing factors, e.g. the plant residue placement, soil environment and ploughing and fertiliser timing, should be considered when establishing new curves.

In conclusion, three different changing inorganic nitrogen progress types may result from plant residues: mineralisation progress, immobilisation-mineralisation progress and immobilisation progress. The mineralisation pattern and immobilisation-mineralisation pattern can be distinguished clearly. However, immobilisation-mineralisation process and immobilisation process are only separated based on the empirical $\mathrm{C}: \mathrm{N}$ value of the plant residues. Several models (as shown in 3.2) are helpful for improving the accuracy of the distinguishing standards when more plant residue properties and soil factors are considered. In addition, those models can quantitatively predict inorganic nitrogen changes. However, models with greater adaptability and accuracy will likely be established in the future.

\section{Synchronism between the soil inorganic nitrogen change patterns and crop nitrogen uptake}

\subsection{Qualitative evaluation}

The rates of average nitrogen accumulation for different crops that including wheat, rice, corn and soybean are presented in Fig. 4. Between 77 and $81 \%$ of the nitrogen was accumulated by rice, corn and soybean between 25 to 34 and 85 to 94 days, i.e. vegetative growth stage. In addition, less than $3 \%$ of the nitrogen was accumulated between 0 and 25 to 34 days, i.e. seedling stage. Finally, 17 to $20 \%$ of nitrogen was accumulated during the reproductive growth stage. Wheat, as an overwintering crop, accumulates $6 \%$ of nitrogen during its seedling stage ( $0-30$ days), $72 \%$ during its vegetative growth stage (30-160 days) and $22 \%$ during its reproductive growth stage (160-230 days). Generally,
Nitrogen uptake percentages (\%)

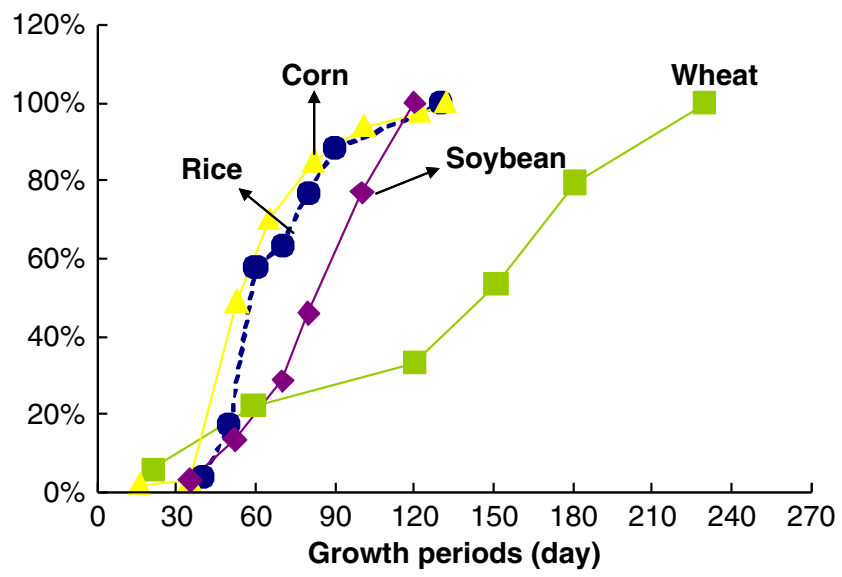

Fig. 4 Nitrogen uptake percentages for the different growth stages of wheat (Cui and Wu 2000; Zhao and Yu 2006), rice (Zou et al. 2002), corn (Zhai 2006) and soybean (Wang et al. 2004). These four staple crops absorb approximately $70-80 \%$ of their nitrogen during their vegetative growth stage and only a small proportion during their seedling stage

crops absorb approximately $70-80 \%$ of their nitrogen during the vegetative growth stage and only a small proportion during their seedling stage. If not enough nitrogen is available in soil with returned plant residues during the soil vegetative growth stage, the yield will be reduced. Conversely, if excessive nitrogen is available during the seedling stage, nitrogen loss may occur.

When the synchronism of the immobilisationremineralisation process and the crop nitrogen demand pattern are low, plant nitrogen assimilation is negatively affected. Ichir and Ismaili (2002) observed that returning lowerquality plant residue (wheat straw) to the soil resulted in a 5month $\mathrm{N}$ immobilisation process at a depth of $0-15 \mathrm{~cm}$. In addition, soil inorganic nitrogen decreased to $61.6,46.4$ and $30.0 \mathrm{mg} \mathrm{kg}^{-1}$ occurred for plant residues that were returned at seeding, at 15 and at 30 days before seeding, respectively. Consequently, the dry matter yield and $\mathrm{N}$ accumulation in the wheat crop decreased. In addition to cereal crop residues, Francis (1995) observed the incorporation of residues from cover crops into soils. These authors found that the yield in the following spring wheat crop decreased by $20-30 \%$ due to extensive net $\mathrm{N}$ immobilisation during residue decomposition. In addition, grain $\mathrm{N}$ uptake and crop yield were also reduced by $\mathrm{N}$ immobilisation when crop straw was retained on the surface (Soon and Lupwayi 2012). However, this effect may change with different crop species. Thomsen and Christensen (1998) reported that lower-quality plant residues incorporation reduced the yield and $\mathrm{N}$ uptake of the first barley test crop. However, the sugar beet yields were unaffected by straw, likely due to their longer growth period. Hemwong et al. (2008) reported that incorporating lower-quality plant residues (sugarcane straw) residue did not significantly affect the growth of legumes due to their $\mathrm{N}_{2}$ fixation capacities.

However, the synchronism can be enhanced by highquality plant residues. For example, Trinsoutrot et al. (2000) 
observed that residues with low $\mathrm{N}$ concentrations induced net $\mathrm{N}$ immobilisation after 168 days $\left(-22\right.$ to $-14 \mathrm{mg} \mathrm{N} \mathrm{g}^{-1}$ of added $\mathrm{C}$ ), but residues with high $\mathrm{N}$ concentrations induced little net immobilisation or mineralisation ( -3 to $+4 \mathrm{mg} \mathrm{N} \mathrm{g}^{-1}$ of added C). In addition, Kumar and Goh (2002) reported that the grain yield and $\mathrm{N}$ uptake of a wheat crop was significantly greater following the return of leguminous residues rather than non-leguminous residues. These authors also indicated that the grain yield of the wheat crop was significantly correlated with the C:N ratio of the residues. Gentile et al. (2009) showed that Tithonia residues treatment resulted in an early season $\mathrm{N}$ release of $22 \mathrm{~kg} \mathrm{~N} \mathrm{ha}^{-1}$ in the upper $30 \mathrm{~cm}$ of the soil profile. However, the maize residues treatment resulted in an immobilisation of $34 \mathrm{~kg} \mathrm{~N} \mathrm{ha}^{-1}$ after $\mathrm{N}$ fertiliser application.

In addition, different plant parts have different influences due to their different chemical properties. Chaves et al. (2004) reported that green manure leaves release more $\mathrm{N}$ than stems and roots. In addition, Thomsen (1993) reported that plant shoots contribute more nitrogen than roots for plant growth. This result was potentially caused by the different lignin concentrations of the residues, which corresponded to $\mathrm{N}$ immobilisation (Dossa et al. 2009).

The inorganic nitrogen changing, which is induced by different plant residues, may affect nitrogen losses differently. Plant residue applications can enhance the role of soil microbes as a temporal $\mathrm{N}$ source or sink, which results in the conservation of potentially leachable $\mathrm{N}$ until a later crop growth phase, especially in years with relatively severe $\mathrm{N}$ leaching (Sugihara et al. 2012). As $\mathrm{N}$ deficiencies can be caused by low-quality residue at the early stage of decomposition (Myers et al.,1994), $\mathrm{N}$ loss risk through leaching also can be reduced (Gentile et al.,2009). However, for high-quality residues, Thomsen and Christensen (1998) observed that sugar beet tops enhanced $\mathrm{N}$ leaching during two winter experimental periods. These results suggested that the effects of plant residues on nitrogen leaching are different for different residue qualities. Generally, the residues qualities are related to the plant residues $\mathrm{N}$ contents, $\mathrm{C}: \mathrm{N}$ ration, lignin contents and so on.

In conclusion, the soils that followed mineralisation process generally promoted nitrogen uptake and resulted in greater yields and a higher risk of nitrogen loss. Although net immobilisation occurred throughout immobilisationmineralisation process and immobilisation process, the uptake of nitrogen by the crops was not necessarily reduced. Instead, the results depend on the synchronism between the changing soil inorganic nitrogen and the crop nitrogen uptake.

\subsection{Synchronism index}

Although the effects of plant residues on soil inorganic nitrogen concentrations have been thoroughly studied, the influences of plant residues on crop nitrogen uptake have not been quantified. Therefore, we propose a conceptual synchronism index (SI) for assessing the synchronism between changing soil inorganic nitrogen concentrations in plant residues that are returned to the soil and crop nitrogen uptake (formula 14). In formula $14, \operatorname{SIN}(t)$ represents the soil inorganic nitrogen concentration in the root layer during the growth period $t$. $\mathrm{AE}[t, \mathrm{SIN}(t)]$ represents the crop inorganic nitrogen assimilation efficiency during growth period $t$ and at a soil inorganic nitrogen concentration of $\operatorname{SIN}(t)$. For plant nitrogen accumulation at time $t$, i.e. $\mathrm{PN}(t)$ (formula 15), we expressed it as the plant nitrogen amount at time $t$, and $\mathrm{C}(t)$ is the plant nitrogen content at time $t, \mathrm{M}(t)$ is the plant weight. The $\mathrm{SIN}(t)$ (formula 16) is expressed in three parts as follows: the inorganic nitrogen from the fertiliser (FN), the inorganic nitrogen from soil mineralisation in the absence of returned plan residues $[\operatorname{SNM}(t)]$, and the inorganic nitrogen change that results from returning plant residues to the soil $[\mathrm{RE}(t)]$. Because the temporal variations of the inorganic nitrogen changes can be expressed by first-order kinetics, first-order kinetics were used to express the $\operatorname{SNM}(t)$ and $\operatorname{RE}(t)$ (formulas 17 and 18). In formula $17, \mathrm{~N}_{0}$ represents the soil mineralisable organic nitrogen, and $m$ represents the rate constant. In formula 18, AN represents the amount of mineralisable $\mathrm{N}$ in the plant residue and $k$ represents the rate constant. For $\operatorname{RE}(t)$, related studies have been based on laboratory data. However, additional studies based on the field data are expected to evaluate the synchronism. Research regarding the $\mathrm{AE}[t, \mathrm{SIN}(t)]$ remains limited. However, the importance of $\mathrm{AE}[t, \mathrm{SIN}(t)]$ for soil nitrogen management may be established gradually.

$\mathrm{SI}=\int_{0}^{T}[\mathrm{SIN}(t) \cdot A E(t, S N(t))-\mathrm{PN}(t)]$

$\mathrm{PN}(t)=\mathrm{C}(t) \cdot \mathrm{M}(t)$

$\operatorname{SIN}(t)=\mathrm{FN}+\operatorname{SNM}(t)+\mathrm{RE}(t)$

$\operatorname{SNM}(t)=\mathrm{N}_{0}\left(1-e^{-\mathrm{mt}}\right)$

$\mathrm{RE}(t)=\mathrm{AN}[1-\exp (-k t)]$

Based on the synchronism index, once the plant $\mathrm{N}$ nutritional demand is satisfied, any residual $\mathrm{N}$ in soil beyond this demand is subject to loss. 


\section{Adjustment measures}

\subsection{Mineralisation process}

Regarding the plant residues that cause mineralisation process in soils, the objective of the adjustment measures is mainly to control inorganic nitrogen losses. Immobiliser and materials for remineralisation were used to adjust mineralisation process.

De Neve et al. (2004) used compost with a high $\mathrm{C}: \mathrm{N}$ ratio, straw and compost with a low $\mathrm{C}: \mathrm{N}$ ratio as immobilisers and molasses for remineralisation to synchronise the residue $\mathrm{N}$ availability with the crop $\mathrm{N}$ demand. In this study, the addition of molasses resulted in strong and significant remineralisation which equivalent to $73 \%$ of the initially immobilised $\mathrm{N}$ during the second stage in the high $\mathrm{C}: \mathrm{N}$ ratio compost treatment. Chaves et al. (2006) used straw as an immobiliser and vinasses (distillation residue in wine industry) for remineralisation to control nitrogen losses from celery residue. This research indicated that the addition of vinasses increased the concentration of remineralised celery- ${ }^{15} \mathrm{~N}$ relative to the straw treatment without vinasses by $6.9 \%$ of celery derived ${ }^{15} \mathrm{~N}$.

Chaves et al. (2005) indicated that stimulating remineralisation of immobilised $\mathrm{N}$ is not easy. The slow progress towards the breaking point of net $\mathrm{N}$ mineralisation and net $\mathrm{N}$ immobilisation indicated that only 12 to $48 \%$ of the immobilised ${ }^{15} \mathrm{~N}$ was remineralised within 2 years after straw incorporation (Thomsen and Christensen. 1998). In this case, the tannic acid and phenolic lignin from the residues potentially cause the nitrogen to become unavailable through covalent binding (Olk et al. 2006; De Neve et al. 2004).

Thus, the immobilizer can effectively reduce $\mathrm{N}$ losses, but immobilized $\mathrm{N}$ cannot be effectively released, in the shortterm, by re-mineralization to satisfy plant $\mathrm{N}$ nutritional demands.

\subsection{Immobilisation-mineralisation process and immobilisation process}

The risk of nitrogen loss is reduced by plant residues that cause immobilisation-mineralisation process and immobilisation process in soils. Therefore, the object of the adjustment measures was to reduce the nitrogen immobilisation that results from these plant residues.

\subsubsection{Ploughing and fertiliser application timing}

Fertiliser nitrogen is an important inorganic soil nitrogen source. The timing of ploughing and fertiliser application affect the immobilisation of fertiliser nitrogen in monoculture farmland.
Ploughing in monoculture farmland should be done in the autumn to avoid serious nitrogen immobilisation during the plant growth period. Carefoot et al. (1994) observed that total plant $\mathrm{N}$ concentrations were reduced following spring ploughing rather than autumn ploughing when straw was incorporated. In addition, autumn ploughing with straw incorporation did not decrease the total plant $\mathrm{N}$ concentration relative to absence of straw.

To enhance the fertiliser nitrogen use efficiency and to avoid large amounts of fertiliser nitrogen immobilisation, fertiliser nitrogen should be applied after plant residues are returned. Carefoot and Janzen (1997) observed that plant $\mathrm{N}$ was derived from fertiliser exhibited a significant interaction between the timing of straw-tillage and fertiliser application. When straw was incorporated in the fall, the plant $\mathrm{N}$ concentrations that were derived from the fertiliser were $44.0 \mathrm{~kg} \mathrm{~N} \mathrm{ha}{ }^{-1}$ for spring-applied $\mathrm{N}$ and $30.6 \mathrm{~kg} \mathrm{~N}^{-1}$ for fall-applied N. Olk et al. (2006) reported that the fertiliser $\mathrm{N}$ recovery was lower for the fall-applied $\mathrm{N}$ relative to the spring-applied N. This result likely occurred due to decreased immobilisation. According to Rosell et al. (1992), the total areal plant dry matter was lowest $\left(4.94 \mathrm{Mg} \mathrm{ha}^{-1}\right.$ ) when $\mathrm{N}$ was added at the beginning of the fallow period, which indicated strong $\mathrm{N}$ immobilisation. In addition, the highest areal plant dry matter $\left(8.30 \mathrm{Mg} \mathrm{ha}^{-1}\right)$ occurred when $\mathrm{N}$ was incorporated during seeding.

Overall, for the plant residues that cause immobilisationmineralisation process and immobilisation process, the fallow period should be long enough for the plant residues to begin decomposition before seeding. In addition, fertilising after the fallow period can reduce the immobilisation of inorganic nitrogen during the crop growth period.

\subsubsection{The locations of the returned plant residues (mulching or incorporated into soil)}

Generally, the decay rates of the residues that were placed on the soil surface are slower than when the residues are incorporated into the soil. In fact, surface-placed residues only decay rapidly when the moisture, nutrient status and soil fauna activity are not limiting (Mando and Stroosnijder 1999; Mando et al. 1999). Coppens et al. (2007) indicated that the decomposition rate of straw depends on the residue location. For example, residue on the surface results in a decomposition rate that is approximately $35 \%$ less than the decomposition rate of incorporated residues. Due to the slow decomposition of surface-applied plant residues, the net release of $\mathrm{N}$ is delayed (Bradford and Peterson 2000). Plant residues that caused immobilisation-mineralisation process or immobilization process in soils cannot prevent the immobilisation of inorganic $\mathrm{N}$ due to their high $\mathrm{C}: \mathrm{N}$ ratios (Bird et al. 2001). However, the extent of immobilisation of surface applied plant residues is lower than for incorporated plant residues. Thus, 
net $\mathrm{N}$ mineralisation is always higher in plant residue mulch treatments relative to incorporation treatments (Coppens et al. 2007).

Despite the improved net $\mathrm{N}$ mineralisation, the grain yield under the mulched treatment was significantly lower than under other management treatments due the lower established plant population (Kumar and Goh 2002). Leaving plant residues on the soil surface creates a cooler and wetter environment than incorporation of plant residues into the soil. In addition, by modelling the gross $\mathrm{N}$ mineralisation and immobilisation, leaving the plant residues on the soil surface increased the risk of nitrate leaching relative to residue incorporation (Coppens et al. 2007). Therefore, the extent of nitrogen immobilisation can be reduced by changing the placement of the plant residue. However, the seeding and nitrogen loss problems must be solved when applying plant residues on the soil surface.

\section{Conclusions}

When plant residues are returned to the soil, they can cause soil inorganic nitrogen changes through biotic immobilisation-remineralisation, abiotic immobilisation, soil organic nitrogen mineralisation, and plant residue organic nitrogen mineralisation. Depending on the occurrence of net immobilisation and its duration within the limited experimental period, the inorganic nitrogen changes process that resulted from the plant residues were divided into three different types. Mineralisation process and immobilisation-mineralisation process can be distinguished based on formulas. However, immobilisation-mineralisation process and immobilisation process can only be distinguished based on empirical plant residue $\mathrm{C}: \mathrm{N}$ values. To predict inorganic nitrogen changes quantitatively, integrated indexes that contain different forms of plant residue carbon and nitrogen and soil properties are more effective than indexes that rely on the $\mathrm{C}: \mathrm{N}$ ratio of plant residues. However, research remains limited for obtaining a universal curve.

Soils with mineralisation process usually promote crop nitrogen uptake, increased yields, and a greater risk of nitrogen loss. Net immobilisation occurs throughout immobilisation-mineralisation process and immobilisation process. However, this immobilisation does not indicate that the uptake of nitrogen by crops will be reduced. In addition, the results depend on the synchronism between the soil inorganic nitrogen change and the crop nitrogen uptake. The conceptual synchronism index was established to evaluate this synchronism. Finally, several measures can be used to adjust the synchronism. As research becomes more advanced, additional methods may be identified that will allow the return of plant residues to soils to become an efficient method for improving farmland nitrogen dynamics.
Acknowledgments We thank two anonymous reviewers and chief editor Dr. Eric Lichtfouse for their valuable suggestions and comments, which led to substantial improvements of this paper, and we would like to thank Dr. Denis Angers for his suggestions for revision. This study was partially supported by the Chinese National Scientific Foundation (no. 31000253 and no.31170490) and the 12th Five-Year Plan of National Key Technologies R\&D Program (no. 2012BAD09B01).

\section{Reference}

Alexander M (1985) Biodegradation of organic chemicals. Environ Sci Technol 19(2):106-111. doi:10.1021/es00132a602

Berg B, McClaugherty C (2008) Plant litter: decomposition, humus formation, carbon sequestration. Springer.

Bird JA, Horwath WR, Eagle AJ, van Kessel C (2001) Immobilization of fertilizer nitrogen in rice. Soil Sci Soc Am J 65:1143-1152. doi:10. 2136/sssaj2001.6541143x

Bradford J, Peterson G (2000) Conservation tillage. In: Sumner ME (ed) Handbook of soil science. CRC, Boca Raton, pp 247-269

Bradley RL, Grenon F (2006) Evidence that straw does not increase the mobilization of $\mathrm{N}$ from decomposing salal (Gaultheria shallon Pursh.) leaf litter. Soil Biol Biochem 38:191-194. doi:10.1016/j. soilbio.2005.04.029

Bussière F, Cellier P (1994) Modification of the soil temperature and water content regimes by a crop residue mulch: experiment and modelling. Agr Forest Meteorol 68:1-28. doi:10.1016/01681923(94)90066-3

Carefoot J, Janzen H (1997) Effect of straw management, tillage timing and timing of fertilizer nitrogen application on the crop utilization of fertilizer and soil nitrogen in an irrigated cereal rotation. Soil Till Res 44:195-210. doi:10.1016/S0167-1987(97)00053-6

Carefoot J, Janzen H, Lindwall C (1994) Crop residue management for irrigated cereals on the semi-arid Canadian prairies. Soil Till Res 32: 1-20. doi:10.1016/0167-1987(94)90029-9

Cassel D, Raczkowski C, Denton H (1995) Tillage effects on corn production and soil physical conditions. Soil Sci Soc Am J 59: 1436-1443. doi:10.2136/sssaj1995.03615995005900050033x

Chaves B, De Neve S, Hofman G et al (2004) Nitrogen mineralization of vegetable root residues and green manures as related to their (bio) chemical composition. Eur J Agron 21:161-170. doi:10.1016/j.eja. 2003.07.001

Chaves B, De Neve S, Boeckx P et al (2005) Screening organic biological wastes for their potential to manipulate the $\mathrm{N}$ release from $\mathrm{N}$-rich vegetable crop residues in soil. Agr Ecosyst Environ 111:81-92. doi: 10.1016/j.agee.2005.03.018

Chaves B, De Neve S, Boeckx P et al (2006) Manipulating the N release from ${ }^{15} \mathrm{~N}$ labelled celery residues by using straw and vinasses. Soil Biol Biochem 38:2244-2254. doi:10.1016/j.soilbio.2006.01.023

Chen J, Ferris H (1999) The effects of nematode grazing on nitrogen mineralization during fungal decomposition of organic matter. Soil Biol Biochem 31:1265-1279. doi:10.1016/S0038-0717(99)00042-5

Compton JE, Boone RD (2002) Soil nitrogen transformations and the role of light fraction organic matter in forest soils. Soil Biol Biochem 34: 933-943. doi:10.1016/S0038-0717(02)00025-1

Coppens F, Garnier P, Findeling A, Merckx R, Recous S (2007) Decomposition of mulched versus incorporated crop residues: modelling with PASTIS clarifies interactions between residue quality and location. Soil Biol Biochem 39:2339-2350. doi:10.1016/j. soilbio.2007.04.005

Cui XZ, Wu GC (2000) Study on nutrient mechanism of NPK fertilizer and its absorbed law of winter wheat with high yield. Chin Agric Sci Bull 16(02):8-11. doi:10.3969/j.issn.1000-6850.2000.02.003 (in Chinese) 
Dail DB, Davidson EA, Chorover J (2001) Rapid abiotic transformation of nitrate in an acid forest soil. Biogeochemistry 54:131-146. doi: 10.1023/A: 1010627431722

Davidson EA, Chorover J, Dail DB (2003) A mechanism of abiotic immobilization of nitrate in forest ecosystems: the ferrous wheel hypothesis. Glob Change Biol 9:228-236. doi:10.1046/j.13652486.2003.00592.x

De Neve S, Hofman G (1996) Modelling N mineralization of vegetable crop residues during laboratory incubations. Soil Biol Biochem 28: 1451-1457. doi:10.1016/S0038-0717(96)00154-X

De Neve S, Gaona Sáez S, Chaves Daguilar B, Sleutel S, Hofman G (2004) Manipulating N mineralization from high N crop residues using on- and off-farm organic materials. Soil Biol Biochem 36: 127-134. doi:10.1016/j.soilbio.2003.08.023

Dossa E, Khouma M, Diedhiou I, Sene M, Kizito F, Badiane A, Samba S, Dick R (2009) Carbon, nitrogen and phosphorus mineralization potential of semiarid Sahelian soils amended with native shrub residues. Geoderma 148:251-260. doi:10.1016/j.geoderma.2008. 10.009

Edwards L, Burney J, Richter G, MacRae A (2000) Evaluation of compost and straw mulching on soil-loss characteristics in erosion plots of potatoes in Prince Edward Island, Canada. Agr Ecosyst Environ 81:217-222. doi:10.1016/S0167-8809(00)00162-6

Erisman JW, Sutton MA, Galloway J, Klimont Z, Winiwarter W (2008) How a century of ammonia synthesis changed the world. Nat Geosci 1(10):636-639. doi:10.1038/ngeo325

Fang S, Xie B, Zhang H (2007) Nitrogen dynamics and mineralization in degraded agricultural soil mulched with fresh grass. Plant Soil 300: 269-280. doi:10.1007/s11104-007-9414-2

Ferris H, Venette R, Lau S (1997) Population energetics of bacterialfeeding nematodes: carbon and nitrogen budgets. Soil Biol Biochem 29:1183-1194. doi:10.1016/S0038-0717(97)00035-7

Ferris H, Venette R, Van Der Meulen H, Lau S (1998) Nitrogen mineralization by bacterial-feeding nematodes: verification and measurement. Plant Soil 203:159-171. doi:10.1023/A:1004318318307

Fontaine S, Mariotti A, Abbadie L (2003) The priming effect of organic matter: a question of microbial competition? Soil Biol Biochem 35: 837-843. doi:10.1016/S0038-0717(03)00123-8

Francis G (1995) Management practices for minimising nitrate leaching after ploughing temporary leguminous pastures in Canterbury, New Zealand. J Contam Hydrol 20:313-327. doi:10.1016/01697722(95)00076-3

Freebairn D, Boughton W (1985) Hydrologic effects of crop residue management practices. Aust J Soil Res 23:23-35. doi:10.1071/ SR9850023

Frey S, Elliott E, Paustian K, Peterson G (2000) Fungal translocation as a mechanism for soil nitrogen inputs to surface residue decomposition in a no-tillage agroecosystem. Soil Biol Biochem 32:689-698. doi: 10.1016/S0038-0717(99)00205-9

Gentile R, Vanlauwe B, Van Kessel C, Six J (2009) Managing N availability and losses by combining fertilizer-N with different quality residues in Kenya. Agr Ecosyst Environ 131:308-314. doi:10.1016/ j.agee.2009.02.003

Gill B, Jalota S (1996) Evaporation from soil in relation to residue rate, mixing depth, soil texture and evaporativity. Soil Technol 8:293301. doi:10.1016/0933-3630(95)00026-7

Griffin DM (1972) Ecology of soil fungi. Chapman \& Hall, London

Hadas A, Kautsky L, Goek M, Erman Kara E (2004) Rates of decomposition of plant residues and available nitrogen in soil, related to residue composition through simulation of carbon and nitrogen turnover. Soil Biol Biochem 36:255-266. doi:10.1016/j.soilbio. 2003.09.012

Havlin J, Kissel D, Maddux L, Claassen M, Long J (1990) Crop rotation and tillage effects on soil organic carbon and nitrogen. Soil Sci Soc Am J 54:448-452. doi:10.2136/sssaj1990. 03615995005400020026x
Heal O, Anderson J, Swift M (1997) Plant litter quality and decomposition: an historical overview. In: Cadisch G, Giller KE (eds) Driven by nature: plant litter quality and decomposition. CAB International, Wallingford, pp 3-30

Hemwong S, Cadisch G, Toomsan B, Limpinuntana V, Vityakon P, Patanothai A (2008) Dynamics of residue decomposition and N2 fixation of grain legumes upon sugarcane residue retention as an alternative to burning. Soil Till Res 99:84-97. doi:10.1016/j.still. 2008.01.003

Ichir LL, Ismaili M (2002) Decomposition and nitrogen dynamics of wheat residues and impact on the wheat growth stages. C R Biol 325:597-604. doi:10.1016/S1631-0691(02)01467-1

Ji S, Unger PW (2001) Soil water accumulation under different precipitation, potential evaporation, and straw mulch conditions. Soil Sci Soc Am J 65:442-448. doi:10.2136/sssaj2001.652442x

Khalil M, Hossain M, Schmidhalter U (2005) Carbon and nitrogen mineralization in different upland soils of the subtropics treated with organic materials. Soil Biol Biochem 37:1507-1518. doi:10.1016/j. soilbio.2005.01.014

Kindler R, Miltner A, Thullner M, Richnow HH, Kästner M (2009) Fate of bacterial biomass derived fatty acids in soil and their contribution to soil organic matter. Org Geochem 40:29-37. doi:10.1016/j. orggeochem.2008.09.005

Kirchner MJ, Wollum A, King L (1993) Soil microbial populations and activities in reduced chemical input agroecosystems. Soil Sci Soc Am J 57:1289-1295. doi:10.2136/sssaj1993.03615995005700050021x

Kumar K, Goh KM (2002) Management practices of antecedent leguminous and non-leguminous crop residues in relation to winter wheat yields, nitrogen uptake, soil nitrogen mineralization and simple nitrogen balance. Eur J Agron 16:295-308. doi:10.1016/S11610301(01)00133-2

Kumar K, Goh KM (2003) Nitrogen release from crop residues and organic amendments as affected by biochemical composition. Commun Soil Sci Plan 34:2441-2460. doi:10.1081/CSS-120024778

Kuzyakov Y, Friedel J, Stahr K (2000) Review of mechanisms and quantification of priming effects. Soil Biol Biochem 32:14851498. doi:10.1016/S0038-0717(00)00084-5

Lal R (1994) Sustainable land use systems and soil resilience. In: Greenland DJ, Szaboles I (eds) Soil resilience and sustainable land use. CAB International, Wallingford, pp 41-46

Liu J, You L, Amini M, Obersteiner M, Herrero M, Zehnder AJ, Yang H (2010) A high-resolution assessment on global nitrogen flows in cropland. Proc Natl Acad Sci U S A 107(17):8035-8040. doi:10. 1073/pnas.0913658107

Mafongoya P, Nair P, Dzowela B (1998) Mineralization of nitrogen from decomposing leaves of multipurpose trees as affected by their chemical composition. Biol Fert Soils 27:143-148. doi:10.1007/ s003740050412

Magid J, Mueller T, Jensen LS, Nielsen NE (1997) Modelling the measurable: interpretation of field-scale $\mathrm{CO}_{2}$ and $\mathrm{N}$-mineralization, soil microbial biomass and light fractions as indicators of oilseed rape, maize and barley straw decomposition. In: Cadisch G, Giller KE (eds) Driven by nature: plant litter quality and decomposition. CAB International, Wallingford, pp 349-362

Mando A, Stroosnijder L (1999) The biological and physical role of mulch in the rehabilitation of crusted soil in the Sahel. Soil Use Manage 15:123-127. doi:10.1111/j.1475-2743.1999.tb00075.x

Mando A, Brussaard L, Stroosnijder L (1999) Termite- and mulch-mediated rehabilitation of vegetation on crusted soil in west Africa. Restor Ecol 7:33-41. doi:10.1046/j.1526-100X.1999.07104.x

Manzoni S, Porporato A (2007) A theoretical analysis of nonlinearities and feedbacks in soil carbon and nitrogen cycles. Soil Biol Biochem 39:1542-1556. doi:10.1016/j.soilbio.2007.01.006

Manzoni S, Jackson RB, Trofymow JA, Porporato A (2008) The global stoichiometry of litter nitrogen mineralization. Science 321:684 686. doi:10.1126/science. 1159792 
Manzoni S, Taylor P, Richter A, Porporato A, Ågren GI (2012) Environmental and stoichiometric controls on microbial carbonuse efficiency in soils. New Phytol 196:79-91. doi:10.1111/j.14698137.2012.04225.x

Mary B, Recous S, Darwis D, Robin D (1996) Interactions between decomposition of plant residues and nitrogen cycling in soil. Plant soil 181:71-82. doi:10.1007/BF00011294

McGregor K, Bengtson R, Mutchler C (1990) Surface and incorporated wheat straw effects on interrill runoff and soil erosion. Trans ASAE 33:469-474

Mohanty M, Probert ME, Reddy KS, Dalal RC, Rao AS, Menzies NW (2010) Modelling $\mathrm{N}$ mineralization from high $\mathrm{C}: \mathrm{N}$ rice and wheat crop residues. In: 19th World Congress of Soil Science.

Mueller T, Jensen L, Nielsen N, Magid J (1998) Turnover of carbon and nitrogen in a sandy loam soil following incorporation of chopped maize plants, barley straw and blue grass in the field. Soil Biol Biochem 30:561-571. doi:10.1016/S0038-0717(97) 00178-8

Mutabaruka R, Hairiah K, Cadisch G (2007) Microbial degradation of hydrolysable and condensed tannin polyphenol-protein complexes in soils from different land-use histories. Soil Biol Biochem 39: 1479-1492. doi:10.1016/j.soilbio.2006.12.036

Myers RJK, Palm CA, Cuevas E, Gunatilleke IUN, Brossard M (1994) The synchronisation of nutrient mineralisation and plant nutrient demand. In: Woomer PL, Swift MJ (eds) The biological management of tropical soil fertility. Wiley, Chichester, pp 81-116

Nishio T, Oka N (2003) Effect of organic matter application on the fate of ${ }^{15} \mathrm{~N}$-labeled ammonium fertilizer in an upland soil. Soil Sci Plant Nutr 49:397-403. doi:10.1080/00380768.2003.10410025

Olk D, Cassman KG, Schmidt-Rohr K, Anders M, Mao JD, Deenik J (2006) Chemical stabilization of soil organic nitrogen by phenolic lignin residues in anaerobic agroecosystems. Soil Biol Biochem 38: 3303-3312. doi:10.1016/j.soilbio.2006.04.009

Paustian K, Agren GI, Bosatta E (1997) Modelling litter quality effects on decomposition and soil organic matter dynamics. In: Cadisch G, Giller KE (eds) Driven by nature: plant litter quality and decomposition. CAB International, Wallingford, pp 313-335

Perucci P, Bonciarelli U, Santilocchi R, Bianchi A (1997) Effect of rotation, nitrogen fertilization and management of crop residues on some chemical, microbiological and biochemical properties of soil. Biol Fert Soils 24:311-316. doi:10.1007/s003740050249

Power J, Broadbent F, Follett R (1989) Proper accounting for N in cropping systems. In: Follett RF(ed) Nitrogen management and ground water protection. Elsevier Science Publishers, pp 159-181.

Rosell R, Galantini J, Iglesias J, Miranda R (1992) Effect of sorghum residues on wheat productivity in semi-arid Argentina. I. Stover decomposition and $\mathrm{N}$ distribution in the crop. Sci Total Environ 117:253-261. doi:10.1016/0048-9697(92)90092-7

Sakala WD, Cadisch G, Giller KE (2000) Interactions between residues of maize and pigeonpea and mineral $\mathrm{N}$ fertilizers during decomposition and N mineralization. Soil Biol Biochem 32:679-688. doi:10. 1016/S0038-0717(99)00204-7

Shindo H, Nishio $\mathrm{T}$ (2005) Immobilization and remineralization of $\mathrm{N}$ following addition of wheat straw into soil: determination of gross $\mathrm{N}$ transformation rates by $15 \mathrm{~N}$-ammonium isotope dilution technique. Soil Biol Biochem 37:425-432. doi:10.1016/j.soilbio. 2004.07.027

Smith JL, Papendick RI, Bezdicek DF et al. (1992) Soil organic matter dynamics and crop residue management. In: Metting Jr FB (ed) Soil microbial ecology: applications in agricultural and environmental management. Marcel Dekker Inc., pp 65-94.
Soon YK, Lupwayi NZ (2012) Straw management in a cold semi-arid region: impact on soil quality and crop productivity. Field Crop Res 139:39-46. doi:10.1016/j.fcr.2012.10.010

Stroo HF, Alexander M (1986) Role of soil organic matter in the effect of acid rain on nitrogen mineralization. Soil Sci Soc Am J 50(5):1219 1223. doi:10.2136/sssaj1986.03615995005000050026x

Sugihara S, Funakawa S, Kosaki T (2012) Effect of land management on soil microbial $\mathrm{N}$ supply to crop $\mathrm{N}$ uptake in a dry tropical cropland in Tanzania. Agr Ecosyst Environ 146:209-219. doi:10.1016/j.agee. 2011.11.008

Sutton MA, Oenema O, Erisman JW, Leip A, van Grinsven H, Winiwarter W (2011) Too much of a good thing. Nature 472(7342):159-161. doi:10.1038/472159a

Taylor BR, Parkinson D, Parsons WF (1989) Nitrogen and lignin content as predictors of litter decay rates: a microcosm test. Ecology 70:97104. doi: $10.2307 / 1938416$

Thomas R, Asakawa N (1993) Decomposition of leaf litter from tropical forage grasses and legumes. Soil Biol Biochem 25:1351-1361. doi: 10.1016/0038-0717(93)90050-L

Thomsen IK (1993) Nitrogen uptake in barley after spring incorporation of $15 \mathrm{~N}$-labelled Italian ryegrass into sandy soils. Plant Soil 150 : 193-201. doi:10.1007/BF00013016

Thomsen IK, Christensen BT (1998) Cropping system and residue management effects on nitrate leaching and crop yields. Agr Ecosyst Environ 68:73-84. doi:10.1016/S0167-8809(97)00134-5

Tian G, Brussaard L, Kang B (1995) An index for assessing the quality of plant residues and evaluating their effects on soil and crop in the (sub-) humid tropics. Appl Soil Ecol 2:25-32. doi:10.1016/09291393(94)00033-4

Trinsoutrot I, Recous S, Bentz B, Lineres M, Cheneby D, Nicolardot B (2000) Biochemical quality of crop residues and carbon and nitrogen mineralization kinetics under nonlimiting nitrogen conditions. Soil Sci Soc Am J 64(3):918-926. doi:10.2136/sssaj2000.643918x

Tu C, Ristaino JB, Hu S (2006) Soil microbial biomass and activity in organic tomato farming systems: effects of organic inputs and straw mulching. Soil Biol Biochem 38:247-255. doi:10.1016/j.soilbio. 2005.05.002

Vigil M, Kissel D (1991) Equations for estimating the amount of nitrogen mineralized from crop residues. Soil Sci Soc Am J 55:757-761. doi: 10.2136/sssaj1991.03615995005500030020x

Wang L, Jinghui L, Keli L et al (2004) The study on the law of nitrogen absorption in soybean. Chin Agric Sci Bull 20(06):162-165. doi:10. 3969/j.issn.1000-6850.2004.06.052 (in Chinese)

Wood C, Edwards J (1992) Agroecosystem management effects on soil carbon and nitrogen. Agr Ecosyst Environ 39:123-138. doi:10. 1016/0167-8809(92)90048-G

Zelenev V, Van Bruggen A, Leffelaar P, Bloem J, Semenov A (2006) Oscillating dynamics of bacterial populations and their predators in response to fresh organic matter added to soil: the simulation model 'BACWAVE-WEB'. Soil Biol Biochem 38:1690-1711. doi:10. 1016/j.soilbio.2005.11.024

Zhai L (2006). The dynamic study on the organism yield and nutrient absorb of corn in different yield treatments. Dissertation, Jilin Agriculture University (in Chinese)

Zhao J, Yu Z (2006) Effects of nitrogen fertilizer rate on uptake, distribution and utilization of nitrogen in winter wheat under high yielding cultivated condition. Acta Agron Sin 32:484 490. doi:10.3321/ j.issn:0496-3490.2006.04.003 (in Chinese)

Zou CM, Daozhu Q, Minggang X et al (2002) Nitrogen, phosphorous and potassium uptake characteristics of rice and its relationship with grain yield. J Nanjing Agric Univ 25(4):6-10. doi:10.3321/j. issn:1000-2030.2002.04.002 (in Chinese) 